\title{
THE ADMINISTRATION OF A TORT LIABILITY LAW IN NEW YORK
}

\author{
JoHN W. MACDONALD*
}

The history of state liability in tort in New York shows a development of sovereign honesty to a degree hardly surpassed in any common law jurisdiction.' There have been setbacks in this progress; some have been due to judicial or administrative conservatism, some to poor legislative draftsmanship, some to insufficient research into background and related topics at the time of amendment of statutes; some to the anomalous position of the Court of Claims in the structure of judicial organization. For the most part, however, the record is extremely progressive. The present Court of Claims Act, ${ }^{2}$ enacted in 1939, provides:

The state hereby waives its immunity from liability and action and hereby assumes liability and consents to have the same determined in accordance with the same rules of law as applied to actions in the supreme court against individuals or corporations, provided the claimant complies with the limitations of this article. ${ }^{3}$

This is as broad an assumption of state liability as could reasonably be demanded.

State liability in New York had modest origins. The board of canal appraisers, created in $1817,{ }^{4}$ was charged with the function of determining the value of real property appropriated by the state in the construction of the Erie Canal. The canal opened in 1825 . In $1829^{5}$ the Legislature passed a statute providing that this agency should have jurisdiction to estimate and appraise the damages sustained by any

*A.B., I925, M.A., I926, LL.B., I926, Cornell University. Clerk of the N. Y. Court of Claims, 19271930. Professor of Law, Cornell University Law School. Executive Secretary and Director of Rescarch, New York Law Revision Commission, since 1935. Frequent contributor to legal periodicals.

${ }^{I}$ See Fleishmann, The Dishonesty of Sovereignties (I910) 33 REP. N. Y. STATE BAR Ass'N 229. MacDonald, Substantive Liability of the State of New York, Adjective Law in Court of Claims (1929) 2 N. Y. State BAR Ass'N Bull. 402; Note (193I) I6 CorN. L. Q. 359.

${ }^{2}$ N. Y. Laws 1939, c. 860 . See also N. Y. Laws 1940, c. 276 , correcting $\$ 29$ of the 1939 statute which had erroneously repealed N. Y. Laws r921, c. 922, instead of repealing, as intended, N. Y. Laws r920, c. 922 .

${ }^{3}$ N. Y. Court of Claims Act, $§ 8$.

N. Y. Laws 1817, c. 262 (found at p. 303 of the volume entitled Laws of 1816). See also N. Y. Laws 1827 , p. 99 (Rev. Stat. 1827, pt. I, c. 9, tit. 9, art. 3). By N. Y. Laws 1816, c. 237, a board of canal commissioners had been appointed "to consider, devise and adopt such measures as may or shall be requisite, to facilitate and effect the communication, by means of canals and locks, between the navigable waters of Hudson's river and lake Eric, and the said navigable waters and lake Champlain." An original appropriation of twenty thousand dollars was provided. Two former statutes were repealed. See N. Y. Laws I8Ir, c. $x 88$ setting up a similar board of canal commissioners and N. Y. Laws $18 \times 2, c$. 23 I conferring further authority on this board. See also N. Y. Laws 1826, c. 314 .

${ }^{5} \mathrm{~N}$. Y. Laws 1829 , c. 48 . 
person "by reason of the breaking away of an embankment on any part of the canals belonging to this state, or of any of the works connected therewith, and which may have been occasioned either by the act or neglect of any commissioner, superintendent or other agent of the state." After such estimate and appraisal, the amount was to be "paid to the owner of the lands to which such damages have been done." It is interesting to note that state liability in tort followed closely upon the construction and operation of one of the first of the great public works undertaken by the sovereign state, and that such liability was limited to the field of this enterprise. Then, too, it should be remarked that this first of general liability statutes was consciously fitted into a respondeat superior pattern, rather than into a mere waiver of immunity from suit-a precedent in draftsmanship which, if it had been observed, would have done much to lessen later difficulties which plagued the New York courts and legislature.

This situation obtained for forty years. In the meantime, thousands of private claim bills were considered by the legislature and many of them were enacted. Many of these bills dealt with claims for injuries resulting from the operation of the canals of the state but outside of the scope of the 1829 statute.

In 1870,8 the legislature passed "an act to provide for the appraisal of canal claims against the State" and granted jurisdiction to the Canal Appraisers to "hear and determine all claims against the State of any and all persons and corporations for damages alleged to have been sustained by them from the canals of the State, or from their use and management, or resulting from the negligence or conduct of any officer of the State having charge thereof, or resulting or arising from any accident or thing connected with the canals," exclusive of "claims arising from damages resulting from the navigation of the canals." The principle was stated that in order to make an award, the facts proved should be of such a character as to "make out a case ... were the same established in evidence in a court of justice against an individual or corporation."."

In 1874 an amendment was adopted to the New York Constitution providing that:

The Legislature shall neither audit nor allow any private claim or account against the State, but may appropriate money to pay such claims as shall have been audited and allowed according to law. ${ }^{\mathbf{1 0}}$

This was part of an elaborate scheme of changes adopted for the purpose of limiting the powers of the legislature in private and local matters, protecting the revenues and property of the state, and improving the standards of public officers. ${ }^{11}$

In 1876,12 a state board of audit, consisting of the Comptroller, the Secretary of

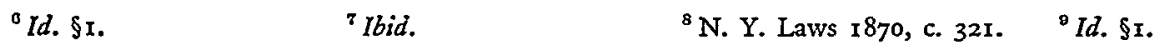

${ }^{10}$ N. Y. Const. 1874 , Art. iii, \$19. See I Rep. N. Y. State Const. Convention Committee (1938) 54,$87 ; 2$ id. at 224-225. The present provision is contained in N. Y. Const., art. iii, \$r9, consolidating former $\$ 19$ of Art. iii with former $\$ 6$ of Art. vii, as amended by Constitutional Convention r93 and approved by the people, Nov. 8,1938 .

12 See i Rep. N. Y. State Const. Convention Commitee (1938) 84-94.

${ }^{13}$ N. Y. Laws 1876, c. 444 . 
State and the State Treasurer was established with "power to hear all private claims and accounts against the State (except such as are now heard by the Canal Appraisers according to law) ... to determine on the justice and amount thereof, and to allow such sums as it shall consider should equitably be paid by the State to such claimants."13 There was no further assumption of liability in this statute.

In $1883^{14}$ both the board of canal appraisers and the board of audit were abolished and a board of claims was established with jurisdiction to "hear, audit and determine all private claims against the state" subject to a definitely stated period of limitation, and with similar power to audit and determine counterclaims in favor of the state. It was likewise given all the jurisdiction and power then possessed by the canal appraisers. ${ }^{15}$ In $1897,{ }^{16}$ the board of claims became a court, the commissioners became judges, and the jurisdiction and powers conferred were the same as those conferred on the board. This court continued to act until IgrI, when it was abolished, ${ }^{17}$ and a board substituted, this time with a personnel different from that of the prior agency. Litigation with regard to the validity of the IgII statute went to the Court of Appeals, which upheld the constitutionality of the action on the ground that the agency was a legislative tribunal existing at the will of the legislature. ${ }^{18}$ No change was made in the IgII statute with regard to the jurisdiction of the tribunal.

In 1915,19 the legislature abolished the board of claims and re-established the Court of Claims, again making no change in the jurisdiction. The situation has con-

${ }^{13} I d$. \$2. $\quad$ "N. Y. Laws 1883, c. 205.

${ }^{15}$ Id. $\$ \$ 7$, 13. A minor increase in the jurisdiction of the board came by N. Y. Laws I884, c. 205 relative to claims arising out of the destruction of diseased animals.

${ }^{10} \mathrm{~N}$. Y. Laws 1897 , c. 36 . In $x 906$ the act was amended to extend the terms of the judges to ten years. See N. Y. Laws 1906 , c. 692. This statute also amended the previous provisions in other regards.

${ }^{17}$ N. Y. Laws I9II, c. 856 .

${ }^{18}$ People ex rel. Swift v. Luce, 204 N. Y. 478,97 N. E. 850 (x912). The legislative nature of the Court was recognized in 1925 by the adoption of an amendment to the Constitution (Art. vi, \$23). In the sixth article, as revised by the Constitutional Convention in 1938 , it was proposed to continue the court as a constitutional court (Art. vi, \$25) as proposed. See Const. Conventron 1938, Doc. No. I6. The sixth arcicle was disapproved by the people, not, however, because of any opposition to this particular section, but as an incident to rejection of the whole article which was submitted as a unit and which contained several controversial provisions, principally one with regard to a constitutional requirement for judicial review of administrative determinations. Since 1938, the Judicial Council has proposed drastic revision of the judiciary (sixth) article of the Constitution. (I94I) Sen. Bill, Intro. No. 1000, Print. Nos. II72, I472; Ass. Bill, Intro. No. 1265, Print. Nos. 1456, x812. The proposal failed to be enacted. In 1939 a specific proposal was made to continue the Court of Claims as a constitutional court, (1939) Sen. Bill, Intro. No. 6r, Print. No. 6r; Ass. Bill, Intro. No. 6o, Print. No. 6o. This proposal likewise failed. In the 1942 session of the Legislature, the Judicial Council made a specific recommendation for revision of the judiciary article to continue the Court of Claims as a constitutional court, (1942) Sen. Bill, Intro. No. 1042, Print. No. 126r; Ass. Bill, Intro. No. 1315, Print. No. 1532. This amendment passed the Senate on March 16, 1942, and the Assembly on March 18, 1942, and was on that day certified to the Secretary of State. Under the provisions of the Constitution relating to amendment, this will be referred to the 1943 Legislature, and, if favorably acted on during that session, it will be submitted to the pcople in such manner as the Legislature prescribes (usually at the next general election, November 1943) for ratification. N. Y. Const., Art. xix, $\$ x$.

${ }^{10}$ N. Y. Laws I915, c. I. This statute added to the jurisdiction of the court the following provision: "It also has jurisdiction to hear and determine a private claim against the state, including the claim of an executor or administrator of a decedent who left him or her surviving a husband, wife or next of kin, for damages for a wrongful act, neglect or default, on the part of the state by which the decedent's death was caused, ..." For discussion of this change, see infra notes 49,51 . 
tinued unchanged since that time, so far as the organization and structure of the agency is concerned. In 1920 , at the time of the adoption of the Civil Practice Act, ${ }^{20}$ the statutory provisions relating to the Court were separated from the general practice provisions (formerly contained in the Code of Civil Procedure ${ }^{21}$ which was repealed in the new consolidation and revision) and were set up in a special practice code as the Court of Claims Act. ${ }^{22}$

In I929 a new section ${ }^{23}$ was added in which the state consented to the imposition of the doctrine of respondeat superior against it, thus reversing the effect of Smith $v$. State, which is discussed below. ${ }^{24}$

In 1939 a general revision of court of claims procedure and organization was accomplished by the repeal of the former Court of Claims Act, and the enactment of a new one. ${ }^{25}$ In the organization of the court the principal changes accomplished were the increase of the court from three to five judges and the deletion of a section providing for additional judges by appointment of the Governor upon a certificate of necessity by the presiding judge of the court. ${ }^{26}$ The court is a court of record, ${ }^{27}$ still legislative in character but with considerable constitutional recognition. ${ }^{28}$ It consists of five judges, ${ }^{29}$ each with an annual salary of $\$ 10,000$, appointed for nine years by the Governor by and with the advice and consent of the Senate. ${ }^{30}$ A judge must be an attorney and counselor at law of at least ten years' experience in practice. ${ }^{31} \mathrm{He}$ may not practice his profession nor act as referee during his term of office, nor hold any other office or public trust during his term. ${ }^{32}$ The court has a clerk, six deputy clerks acting as court stenographers, and the necessary administrative staff. ${ }^{33}$ The court is required to furnish to the Judicial Council of the state such reports and information as may be required by the Council. ${ }^{34}$ It has a considerable rule-making power. ${ }^{35}$ Except as otherwise provided by the Act or by such rules, the practice is the same as in the Supreme Court of the state. ${ }^{36}$ The court has the power by rule to provide for the terms and places of its sittings and to prepare the calendars for such terms. ${ }^{37}$ Three terms of court are held annually in the city of Albany; two terms are held annually in the cities of Buffalo, New York, Rochester, Syracuse and Utica; one term is held annually in either Binghamton or Elmira. ${ }^{38}$ Special terms may also be held at other places. ${ }^{39}$ The state has been divided geographically into seven districts. Claims arising in the various districts are assigned by the clerk in the preparation of his calendar to the appropriate place of trial.40 The sheriff of

\footnotetext{
${ }^{30}$ N. Y. Laws 1920, c. 925. $\quad 21$ N. Y. CODE Crv. Proc., tit. III, art. $1, \$ \$ 263-282$.

${ }^{22}$ N. Y. Laws 1920 , c. 922 . $\quad{ }^{23}$ N. Y. Laws I929, c. 467 , adding Court of Claims Act, §12-a.

24 Notes 48-5I, infra.

${ }^{25} N$. Y. Laws I939, c. 860; Laws I940, c. 276 , supra note 2.

${ }^{20} \mathrm{~N}$. Y. Court of Claims Act, $\$ 2 . \quad{ }^{27}$ N. Y. Judiciary Law, \$2.

${ }^{29}$ See stupra note I8; N. Y. Const., art. iii, §rg; art. vi, \$23.

${ }^{20} \mathrm{~N}$. Y. Court of Claims Act, $\$ 2$. ${ }^{30} I d$. $\$ \$ 2,4$.

${ }^{31}$ Id. $\$ 2$.

${ }^{83}$ Id. \$5. Sec N. Y. Laws 1942, c. 91. $\quad 34$ N. Y. Court of Claims Act, \$7(2).

${ }^{36} I d$. $\$ 9(9)$. See Rules of the N. Y. Court of Claims, adopted Nov. 13, 1939.

${ }^{30}$ N. Y. Court of Claims Act, $\$ 9(9)$. ${ }^{37}$ Id. $\$ 9$ (10).

${ }^{58}$ Rules of the N. Y. Court of Claims, Rules I, 3. ${ }^{30}$ Id. Rule I.

${ }^{10} \mathrm{Id}$. Rules 2, 3.
} 
each of the various counties of the state, except in Albany, is required to furnish suitable rooms in the courthouse of his county for any session held therein. ${ }^{41}$ In Albany, the court occupies chambers in the State Capitol. ${ }^{42}$

\section{Substantive Liabizity of The State}

Reference has already been made to the limited waiver of liability contained in the 1829 statute $^{43}$ relating to the board of canal appraisers, and to the 1870 statute $^{44}$ granting jurisdiction to that agency to "hear and determine all claims against the state ... for damages alleged to have been sustained ... from the canals," etc. The I874 constitutional amendment ${ }^{45}$ will also be remembered, and the consequent establishment of a board of claims in $1883,{ }^{46}$ subsequently to become a court. ${ }^{47}$ It will be noted from all of these statutes that jurisdiction of a stated tribunal and consent of the sovereign to suit were intermingled in one statutory provision. There were, however, various other consent statutes, which will be discussed below. No difficulty arose with this type of statute in the three principal types of cases which came before the court until 1920. In canal damage cases, the waiver of immunity was broad; the liability of the state had a firm basis resting on the very foundations of sovereign consent to suit; the interests involved had long been recognized and respected. In land appropriation cases, the constitutional requirements governing eminent domain probably caused the courts to avoid technical restrictions upon the scope of state liability. Probably the very convenience of the tribunal itself, the broad language of the consent statute, and the desirability of maintenance of state credit caused the avoidance of similar limitations in contract actions. Of course, it is not the purpose of this paper to discuss elaborately the ramifications and limitations of the substantive law of state liability either in land appropriation cases (quite similar to a quasicontractual liability) or in contract, or in tort.

It is, however, important to consider a phase in the history of tort liability, marked by a decision of the Court of Appeals ${ }^{48}$ that a statute written in terms of waiver of consent did not subject the state in tort cases to the rule of respondeat superior, and concluded by an express statutory provision reversing the rule so declared. The ruling appears to have been quite unnecessary and nearly incredible when one considers the form of the statute which was being construed.

In I915, the consent statute conferring jurisdiction on the Court of Claims read as follows:

The court of claims possesses all the powers and jurisdiction of the board of claims. It also has jurisdiction to hear and determine a private claim against the state, including a claim of an executor or administrator of a decedent who left him or her surviving a husband, wife- or next of kin, for damages for a wrongful act, neglect or default, on the part of the state by which the decedent's death was caused, which shall have accrued within

${ }^{41} \mathrm{~N}$. Y. Court of Claims Act, $\$ 13$.

42 Its courtroom was formerly occupied by the Second Division of the Court of Appeals during its short-lived history.

${ }^{43}$ Supra note 5. " 4 Supra note 8. ${ }^{45}$ Supra note xo. ${ }^{40}$ Supra note 14. "

${ }^{4}$ Smith v. State, 227 N. Y. 405 , I25 N. E. 84 I (1920). 
two years before the filing of such claim and the state hereby consents, in all such claims, to have its liability determined. . . . In no case shall any liability be implied against the state, and no award shall be made on any claim against the state except upon such legal evidence as would establish liability against an individual or corporation in a court of law or equity. ... ${ }^{49}$

On April 25, I9I5, claimant, Smith, who was within the park known as the State Reservation at Niagara tripped and fell over a wire string on iron posts along the edge of the path, assumed arguendo to have been put there by the negligence of officers and agents of the state. The Court of Appeals held in I920, on an appeal from a judgment in favor of claimant, that the section quoted above was enacted not "for the purpose of extending or enlarging the liability of the state, but solely for the purpose of declaring the jurisdiction of the Court of Claims, before which questions of liability might be tried." The court continued:

But it is thoroughly established that by consenting to be sued, the state waives its immunity from action and nothing more. It does not thereby concede its liability in favor of the claimant or create a cause of action in his favor which did not theretofore exist. It merely gives a remedy to enforce a liability and submits itself to the jurisdiction of the court, subject to its right to interpose any lawful defense. Immunity from an action is one thing. Immunity from liability for the torts of its officers and agents is another. Immunity from such liability may be waived by some positive enactment of the legislature. This, as I read the section of the Code under consideration, the legislature has not yet done.50

Two judges dissented. As might be expected the decision was severely criticized. ${ }^{51}$

There were other statutes assuming, in general terms, a tort liability in specific types of cases, which antedated this decision. Reference has already been made to the canal statute. ${ }^{52}$ Quite a similar liability had been assumed for injuries resulting from defects in highways. ${ }^{53}$ But for the injuries to persons or property resulting

"Supra note I9. CODE Crv. Proc., $\$ 264$.

${ }^{60} 227$ N. Y. at $409-410$.

t1 See e.g., Note (1920) 5 Corn. L. Q. 338,340 :

“. . . Is it possible that jurisdiction was meant to be conferred merely to permit the claimant to amuse himself? Is the Court of Claims a gymnasium within which claimants may exercise, or is jurisdiction conferred upon it to permit the settlement of disputed rights, assuming there may be a right if proper evidence is produced? . . ." One might inquire what the purpose of the Legislature in 1915 was in inserting the death action clause (supra note 19 ). It could as well be argued that this too was merely a waiver of immunity from action, and not a definite assumption of substantive liability. Perhaps, if the $S m i t h$ case had been a death action, the result would have been the same, despite the specific character of the clause and its recent insertion by the Legislature. It is an interesting speculation, on the other hand, to wonder what the result would have been if the question had arisen first in a death case. Would the court have held that the definite change in I9I5 was meaningless? Might the Court have said simply that the intent was clear but the attempt failed? Or would claimant-estate have been permitted to recover? Would this latter result have been considered a precedent in a personal injury or property damage action so as to have permitted Smith to recover?

This decision might be said to have been unexpected. See Law Revision Comm'N, Report, RecomMENDATIONS AND Studies (1936) 953-954 n. 3. For thirty-five years it was generally believed that section 12 completely waived immunity. Awards had been made by the lower courts. See Burke v. State, 64 Misc. 558, r 19 N. Y. Supp. I089 (Ct. Cl., 1909); Arnold v. State, $x 63$ App. Div. 253, I48 N. Y. Supp. 479 ( $3 \mathrm{~d}$ Dept., I914), and other cases cited in the Law Revision Commission study. See dicta of the Court of Appeals in People ex rel. Swift v. Luce, 204 N. Y. 478, 484, 97 N. E. 850 (1912) and in Quayle v State, 192 N. Y. $47,50,84$ N. E. 583 (1908). See also (rgrg) 5 ConN. L. Q. 78, 84 ; Fleishmann, The Dishonesty of Sovereignties (rgro) 33 REP. N. Y. STATE BAR Ass'N 229, 250.

${ }^{62}$ Supra note 5. See New York Canal Law, $\$ 120 . \quad{ }^{63}$ New York Highway Law, $\$ 58$. 
from the activities of the state in all of its other activities, there was no general liability statute. The result was to be expected: a veritable flood of private claim bills, not in the form of specific appropriations of money to the injured person, for the Constitution prevented that, but in the form of particular grants of jurisdiction to the Court of Claims with waivers of "immunity from liability" granted in one form or another in the named case, ${ }^{54}$ as the subject of each bill. All of the old defects of the practice were present: insufficient investigation on the part of the legislature; assumption of the judicial function by the executive in determining the merits of particular cases in considering whether to approve or disapprove the bill; uneven distribution of justice; lack of uniformity in the various assumptions of liability. ${ }^{\text {t5 }}$

In I929 Section I2-a of the Court of Claims Act was enacted, providing as follows: ${ }^{56}$

The state hereby waives its immunity from liability for the torts of its officers and employees and consents to have the same determined in accordance with the same rules of law as apply to an action in the supreme court against an individual or corporation, and the state hereby assumes liability for such acts, and jurisdiction is hereby conferred upon the court of claims to hear and determine all claims against the state to recover damages for injuries to property or for personal injury caused by the misfeasance or negligence of the officers of the state while acting as such officer or employee. Such claim must be submitted pursuant to the procedural provisions of the court of claims act. Nothing herein contained shall be construed so as to affect, alter or repeal any provision of the workmen's compensation law.

The waiver of immunity was thus in the broadest possible terms. In I939 a new Court of Claims Act was enacted, repealing the former statute, and the waiver was written in its present form: $:^{57}$

The state hereby waives its immunity from liability and action and hereby assumes liability and consents to have the same determined in accordance with the same rules of law as applied to actions in the supreme court against individuals or corporations, provided the claimant complies with the limitations of this article.

Under these sections, the state has attempted to assume as broad a liability in tort as that imposed on individuals and private corporations. Under them, the state has been held liable for an assault by a state police sergeant in attempting to make an arrest without making a reasonably careful identification of an automobile, and without informing claimant that the arresting person was a police officer. ${ }^{58} \mathrm{~A}$ state trooper is held to be an employee of the state within Section 12-a (present Sec-

\footnotetext{
54 Of course there was considerable difficulty in obtaining the enactment of claim bills. The session laws for various years will indicate a liberal or a strict point of view of various administrations with regard to them. Likewise a study will show interesting variations in the form of the bills with regard to probative requirements, defense of contributory negligence, and similar issues.

55 The legislative process in New York provided no real opportunity for investigation and consideration of these bills. The Governor obviously would have to depend on the suggestion and advice of his counsel after little real opportunity for study of the merits of the individual cases.

${ }^{50}$ N. Y. Laws 1929, c. 467.

${ }^{57}$ N. Y. Court of Claims Act, $\$ 8$, enacted by N. Y. Laws r939, c. 860.

${ }^{58}$ Egan v. State, 255 App. Div. 825, 7 N. Y. S. (2d) 64 (4th Dept., 1938).
} 
tion 8). ${ }^{59}$ Likewise the state has been held for conversion, ${ }^{60}$ and for interference with a contractor's work by an order to continue preliminary work, thereby causing delay. ${ }^{01}$

Of course, the most extensive source of claims is negligence. The state has been held liable for negligence of state troopers in failing to transmit an order canceling a former order for the arrest of claimant's intestate, who was killed in resisting arrest by a plain-clothes man. ${ }^{62}$ It has been held liable for negligence of its own truck drivers, ${ }^{03}$ for the negligent failure of a state engineer to warn that a road was under construction, ${ }^{64}$ and for the negligent continuance of a defective culvert in a state highway. ${ }^{65}$ It is liable for falling rocks from a mountain owned by the state, when rocks had fallen previously during thawing periods, ${ }^{66}$ and for negligent failure to maintain proper safeguards in state properties, such as parks, to protect the public. ${ }^{67}$ The same rules as would be applied to the private tort-feasor are, however, imposed. The claimant must demonstrate that the proximate cause of the injury was the negligence of the state. ${ }^{68}$ And, of course, contributory negligence will bar a recovery. ${ }^{69}$

It will be noted that the all too familiar distinction between governmental and proprietary functions of the state is not made. The state has long been liable for the operation of its canals. ${ }^{70}$ It is equally liable in the maintenance of its highways. ${ }^{71}$ It has been held liable for negligence for the activities of its police officers, ${ }^{72}$ for injuries resulting from negligence in its hospitals, ${ }^{73}$ and its schools. ${ }^{74}$ Unquestionably it is equally liable for injuries which result from negligent conditions in public buildings. Construing the statute assuming liability, the Court of Appeals in Paige v. State, ${ }^{75}$ has gone so far as to hold that the state is subject to a judgment for damages in favor

${ }^{60}$ Mowers v. State, 168 Misc. 651,6 N. Y. S. (2d) 408 (Ct. Cl., 1938).

${ }^{10}$ American Engineering Co. v. State, I52 Misc. 528, 273 N. Y. Supp. 853 (Ct. Cl., I934); Lacka. wanna Steel Corp. v. State, I52 Misc. 604, 273 N. Y. Supp. 895 (Ct. Cl., x934).

${ }^{\circ 2}$ American Bridge Co: v. State, 245 App. Div. 535, 283 N. Y. Supp. 577 (3d Dept., I935).

02 Slavin v. State, 249 App. Div. 72, 291 N. Y. Supp. 721 (3d Dept., I936).

${ }^{13}$ Smith v. State, 268 N. Y. 55I, 198 N. E. 400 (I935); Tooley v. State, 235 App. Div. 656, 255 N. Y. Supp. 846 (4th Dept., I932).

"Miller v. State, 23I App. Div. 363, 247 N. Y. Supp. 399 (3d Dept., I93 I).

of Logan v. State, I62 Misc. 793, 296 N. Y. Supp. 639 (Ct. Cl., 1937), affd, 254 App. Div. 4Io, 5 N. Y. S. (2d) 908 (3d Dept., 1938).

${ }^{\circ B}$ Shaknis v. State, 25I App. Div. 767, 295 N. Y. Supp. 663 (3d Dept., I937); Doulin v. State, 277 N. Y. 558,13 N. E. (2d) 472 (1938).

${ }^{07}$ Grifin v. State, 250 App. Div. 244, 295 N. Y. Supp. 304 (3d Dept., r937) (no negligence on part of state proved in this case and recovery denied).

${ }^{08}$ Dooley v. State, 254 App. Div. 381, 5 N. Y. S. (2d) 760 (3d Dept., 1938), aff'd, 280 N. Y. 748, 21 N. E. (2d) 518; Brand v. State, 250 Aṕp. Div. 810, 294 N. Y. Supp. 215 (3d Dept., 1937).

${ }^{\circ 0}$ Ruggiero v. State, 256 App. Div. 437, 10 N. Y. S. (2d) 242 (3d Dept., 1939); Kelly v. State, 253 App. Div. 77r, I N. Y. S. (2d) 3 (3d Dept., 1937); Ryer v. State, 249 App. Div, 694, 29 r N. Y. Supp. 234 (3d Dept., 1936); Everett v. State, I66 Misc. 58, 2 N. Y. S. (2d) II7 (Ct. Cl., 1938); Countryman v. State, I59 Misc. 846, 288 N. Y. Supp. 234 (Ct. Cl., I935), rev'd, 277 N. Y. 586, I3 N. E. (2d) 782 (1938) (Court of Appeals holding that proof of contributory negligence was unsubstantial).

${ }^{70}$ Supra notes 52,5 .

${ }^{71}$ Supra note 53.

${ }^{73}$ Egan v. State, supra note 58. Cf. Arnold v. State, 280 N. Y. 326,20 N. E. (2d) 774 (x939) (finding of no negligence held sustained).

${ }_{73}$ Spataro v. State, I66 Misc. 4 ×8, 3 N. Y. S. (2d) 737 (Ct. Cl., 1937).

7 Agnew v. State, 166 Misc. 602, 2 N. Y. S. (2d) 954 (Ct. Cl., 1938) (special statute).

${ }^{76}{ }_{29}$ N. Y. 352 , 199 N. E. 617 (1936). 
of an inmate of a private correctional institution subject to state visitation, inspection and supervision. ${ }^{76}$ The inmate, a misdemeanant, was directed without adequate instruction, to operate an ironing machine and while so engaged, was injured without her fault, through the defective operation of the machine. It was held that the negligence of those in charge of the institution, employees of the institution and not of the state, was a tort of officers and employees of the state within the meaning of section I2-a of the Court of Claims Act. The court did not assume any negligence by those who had the duty of visitation and supervision on behalf of the state; in fact it excluded this from consideration. The negligence was considered to be solely that of the employees of the institution itself. And the court conceded the function to be governmental: ${ }^{77}$

The quasi-penal institution in which the claimant was confined was a governmental agency to which the State had committed in part its function to care for wayward minors.

Two judges dissented and expressed the fear that a "decision that the corporation, while exercising a governmental function, acts as agent of the State, and that the State, except for its governmental immunity, is responsible for the torts of the corporation employed by it," may carry the consequence that employees of the corporation are employees of the state itself. ${ }^{88}$

Later, an ingenious claimant sued the state to recover for a fire loss occasioned by the failure of a municipal corporation to provide sufficient fire protection, on the theory that the state delegates its governmental function to municipalities, that the failure of the city is the failure of the state and that fire protection is clearly a governmental function. The Appellate Division refused to hold that the Paige case made the state liable for the torts of municipalities. ${ }^{70}$ Nor would the Court of Claims permit a claimant to recover for the inadequate inspection of elevators in private property and consequent failure to disclose the negligence of the property owner in not maintaining safe elevators. ${ }^{80}$ Prior to the enactment of Section $12-\mathrm{a}$ the Appellate Division correctly had refused to hold the state liable for loss to depositors due to negligent mismanagement of a private bank, even assuming negligence upon the part of state banking examiners. ${ }^{81}$

On the other hand, in a case which involved a claim against the state for the death of decedent which occurred, while he was in the military service of the state, by reason of the negligence of a fellow private and an officer, the court denied a recovery ${ }^{82}$ The first reason for this conclusion stated by the court is that the pension

${ }^{70}$ See (1936) 22 CoRN. L. Q. 87, in which the author suggests that the institution being elecmosynary might be immune from suit; Hamburger v. Cornell University, 240 N. Y. $328,1_{4} 8$ N. E. 539 (1925). See McCaskill, Respondeat Stuperior as Applied in New York to Quasi Public and Eleemosynary Corporations (1920) 6 CoRn. L. Q. 56. Cf. Dillon v. Rockaway Beach Hospital, 284 N. X. 176, 30 N. E. (2d) 373 (1940).

${ }_{78}^{369}$ N. Y. 352,356 , 199 N. E. 617 (1936).

${ }^{78} 269$ N. Y. at 359.

${ }^{70}$ Hughes v. State, 252 App. Div. 263, 299 N. Y. Supp. 387 (3d Dept., 1937).

${ }^{80}$ Chastaine v. State, 160 Misc. 828,290 N. Y. Supp. 789 (Ct. Cl., 1936).

${ }^{81}$ Sherlock v. State, 198 App. Div. 494, I91 N. Y. Supp. 412 (3d Dcpt., 192I).

${ }^{82}$ Goldstein v. State, 28I N. Y. 396,24 N. E. (2d) 97 (r939). 
provisions contained in the Military Law (\$\$220-224) are exclusive. The court then construed Sections I2 and r2-a of the Court of Claims Act as not including members of the militia as being officers and employees of the state and that "therefore the State has not waived its immunity for liability for their torts." The court had already stated that to hold otherwise would be "startling." It went on:

True it is that if the word "officers" is given its broad meaning, it would include every officer engaged in performing a duty placed upon him by law, including the Governor, judges, members of the Legislature and all others occupying an official position in the State. Such an interpretation of the statute would lead to an absurd conclusion. The history of the development of our form of government demonstrates that officials in performing certain functions of government cannot by their official acts create a liability against the State by their negligent performance. The language used in former section 12-a must be given a reasonable construction, consistent with our conception of governmental functions and public policy. ${ }^{83}$

Does this language indicate the presence of a lingering judicial doubt based on the maintenance of a distinction between a limited kind of governmental as opposed to a private function of the state? Or is the court seeking to raise again the old test of discretionary as opposed to ministerial activity? Certainly we can concede that the legislature did not intend to make all negligence of state employees and officers actionable. There has been no contention made that those who are injured by the negligent mistakes of trial judges in either civil or criminal cases can recover against the state by reason of the assumption of liability in Section r2-a. All that the state did was to "waive its immunity from liability for the torts of its officers and employees." And without expressly defining torts the state expressly "consented to have its liability determined in accordance with the same rules of law as apply to an action in the supreme court against an individual or a corporation." It is certainly legitimate to inquire whether specific negligence of a public officer would be actionable under such a test, and whether it therefore is a tort. Certainly judges in New York are not personally actionable for their mistakes, even if "negligent," and therefore respondeat superior does not apply. There is, however, no reason why a judge negligently driving a car on official business, should not be liable even though a judge, and why his negligence should not be imputed to the state. This court, however, conceding that, under the findings an individual or corporation might be held liable for negligence, states: "But it is not true that whenever an individual is liable for a certain act the State is liable for the same act." 84 For this the case of Barrett $v$. State ${ }^{85}$ is cited, a case decided before the enactment of Section I2-a, and dealing with liability for the consequences of the enactment and operation of a statute itself. ${ }^{86}$

\footnotetext{
${ }^{83}$ Id. at $405 . \quad{ }^{84}$ Id. at $406 . \quad{ }^{85} 220$ N. Y. 423,116 N. E. 97 (I917).
}

${ }^{80}$ In this case, claimant sought to recover against the state for damage to real property caused by beaver, basing his claim on the legislative policy adopted in protecting beaver by statute. The court, reversing the Appellate Division and the Court of Claims, held for the state and dismissed the claim. The statute protecting beaver was held constitutional. But even if unconstitutional "We know of no principle of law under which the state becomes liable because of the adoption of an unconstitutional statute." Id. at 429,430 . 
One who would agree thoroughly with the result in each of these cases well might deplore any language or interpretation which would lend itself to future resurrections of governmental-private, or discretionary-ministerial distinctions in the law of state liability in New York.

Another instance of continued immunity of the state despite the general principle of liability is found in the disability of felons to sue the state. ${ }^{87}$ This result, however, is not compelled by any narrow conception of governmental function in the management of state prisons. Indeed the Paige case ${ }^{88}$ held the state liable to a prisoner, a misdemeanant, where the confinement was in a private institution. With regard to prisoners sentenced to state prisons, felons under the test applied in New York, the Penal Law provides for a suspension, during the term of the sentence, of all the civil rights of the person sentenced. ${ }^{82}$ The extension of the statutes of limitations by reason of such imprisonment is often not long enough to permit the prisoner to sue after his release. ${ }^{90}$ Unfortunately the Court of Claims has felt compelled to hold that this bar extended to a prisoner while on parole..$^{91}$ These unfortunate results of the Penal Law provision are not by any means defenses solely available to the state. They are equally applicable to any alleged tort-feasor whether the tort occurs prior to or during the term of incarceration. ${ }^{92}$

There are other advantageous rules of law which the state has available to it by reason of its sovereign position. Notable among them is the well-established holding that the state is liable for certain consequential damages arising out of public improvements only if property of the claimant is actually taken by eminent domain. For example, the state is not liable for consequential damages caused to owners of property by change of grade of public highways, relocation of streets or bridges, or destruction of ingress or egress. ${ }^{93}$ On the other hand, the state is liable for such damage if it is an incident to a claim made for the direct appropriation of property, as an item of valuation of property taken.94

Despite Section I2-a with its general assumption of liability, certain limited liability statutes dealing with specific situations remain on the books. Under the oldest of all of the respondeat superior statutes, a section re-enacted in 1939, Section 12-a is excluded from the canal liability situation. Under the section in the Canal Law, the

${ }^{87}$ Green v. State, 278 N. Y. 15, 14 N. E. (2d) 833 (1938), aff'ing 251 App. Div. 108, 295 N. Y. Supp. 672 (1937). See Note (1937) 23 CorN. L. Q. 184 .

${ }_{88}^{8}$ Supra note 75 .

${ }^{80}$ See N. Y. Civil Practice Act, $\$ \$ 43,60$.

${ }^{21}$ Lehrman v. State, I76 Misc. 1022, 29 N. Y. S. (2d) 635 (Ct. Cl., 1941).

${ }^{92}$ See La Chapelle v. Burpee, 69 Hun 436, 23 N. Y. Supp. 453 (3d Dept., r893); Kugel v. Kalik, 176 Misc. 49, 25 N. Y. S. (2d) 327 (Sup. Ct., I94I); In re Weber's Estate, 165 Misc. 815, I N. Y. S. (2d) 809 (Surr. Ct., 1938) (prisoner may, however, defend a suit); Application of White, 166 Misc. 481, 2 N. Y. S. (2d) 582 (Ct. Cl., x938). See also (I934) Ops. ATr'y GeN. 51, St. Dept., 74; (1933) Ops, Atr'Y Gen. 5I9; (1915) Ops. ATT'y Gen. 76.

The N. Y. Law Revision Commission has reported to the Legislature that it has this topic under consideration. See N. Y. Leg. Doc. (1942) No. 65, at 15.

${ }^{93}$ Van Aken v. State, 26 I N. Y. 360, I85 N. E. 397 (I933); Miller v. State, 229 App. Div. 423, 243 N. Y. Supp. 212 (3d Dept., 1930) and cases cited therein.

"Van Aken v. State, supra note 93, at 362 . "Such consequential damages as may be awarded are those resulting from a direct taking." 
liability of the state does not extend to claims arising from damages resulting from the navigation of canals. ${ }^{95}$ This exception from liability is one which goes back to the beginning of state liability in New York.

The most troublesome of all such conflicts between special liability provisions and the general statutes is caused by Section $5^{8}$ of the Highway Law. ${ }^{96}$ Long before Section I2-a was enacted, the state, under certain circumstances of supervision, had assumed liability for defects in the highways during certain months in the year. There was absolute immunity during the excepted months. When Section I2-a was enacted the Highway Law provision remained. With the two statutes in force, if the injury resulted from a highway "defect," the state is liable only between May I and November I5, but if the injury resulted from negligence of an officer or employee of the state the liability continues throughout the year. ${ }^{97}$ The result of this situation has been a multitude of cases attempting to distinguish between situations as defects or as personal negligence, a distinction most unworkable in actual practice. Of course the state in limiting liability for "defects" sought to prevent liability for failure to remove snow and ice from the roads, but if there is to be liability for that situation at all, it is certainly because of the occurrence of personal negligence rather than because of the existence of a defect in the highway, and the liability of the state for snow and ice would thus arise under Section $12-a^{98}$ The situation has been criticized both on practical and on logical grounds. ${ }^{99}$ Legislation has been proposed to correct the difficulty, but has failed of enactment. ${ }^{100}$ Finally in 1939 a case was decided

\footnotetext{
${ }^{05}$ See N. Y. Canal Law, §r2o: "provided that the provisions of this section shall not extend to claims arising from damages resulting from the navigation of canals, and further provided that the provisions herein relating to damages resulting from navigation of the canals shall control notwithstanding any contrary or inconsistent provisions of any other law, general or special." See notes 8, 9 supra.

${ }^{00}$ Supra note 53.

${ }^{07}$ See Miller v. State, 231 App. Div. 363, 247 N. Y. Supp. 399 (3d Dept., I93I); Hinds v. State; I44 Misc. 464,258 N. Y. Supp. 748 (Ct. Cl., 1932), aff'd $w$. op., 240 App. Div. 742, 265 N. Y. Supp. 964 (3d Dept., 1933), affd w. op., 264 N. Y. 525, r9r N. E. 547 (1934). See Fernbach v. State, 148 Misc. 446, 265 N. Y. Supp. 381 (Ct. Cl., I933); Killoran v. State, 155 Misc. 26, 278 N. Y. Supp. 659 (C. Cl., I935). In the Fernbach case, the injury resulted from the car being. thrown into a ditch by reason of the presence of a narrow ridge of dirt being left in the highway during repair broadening out gradually to prevent straddling. Held, governed by Court of Claims Act, \$12-a, negligence of officers and employees. In the Killoran case the injury resulted from skidding on an asphalt patch negligently left unattended by the highway department for three years. Held, governed by Highway Law, $\$ 176$ (now \$58), defect in highway. These cases are presented only as illustrations; many more have occasioned difficulty. See Note (193I) I6 CoRN. L. Q. 359, 364: "To conceive of a negligent defect that is not a tort within section I2-a requires the services of a metaphysician." In I936, the New York Law Revision Commission recommended a bill to the Legislature to resolve the conflict. See (I936) Sen. Bill Intro. No. 1242. Print. Nos. I44I, 233I, Ass. Bill Intro. No. I52I, Print. Nos. 17I3, 24I8, 257I, Sen. Bill No. 2595. This bill passed the Legislature but was vetoed by the Governor on May 29, 1936. See Law Revision Comm'N stipra note 5r, at 943-99I, 1028-1029.

${ }^{08}$ For a general discussion, more particularly directed to municipal and private liability, see De Graff, Snow and lce, A Disctussion of Liability under the Laws of New York (I936) 2 I CoRN. L. Q. 436. See Brand v. State, 250 App. Div. 8ro, 294 N. Y. Supp. 215 (3 Dept., 1937), a snow and ice case, if due to a defect, accident happened outside period; no negligence of state officers and employees shown. "Fear of an excessive number of snow and ice cases is unfounded, as the state is not an insurer but would be responsible for only such snow and ice conditions as were caused by the negligence of its officers and employees; only reasonable care is required," Note (I939) 25 ConN. L. Q. r40, 143 .

${ }^{\circ B}$ See stupra note 97 200 Ibid.
} 
which may well have settled the question. ${ }^{101}$ In $193^{8}$ the Appellate Division of the Third Department, ${ }^{102}$ held that damages caused by a defect in the highway were also the result of the negligence of state officers and employees. ${ }^{103}$ That same year the Appellate Division of the Fourth Department in Karl v. State ${ }^{104}$ did not follow this reasoning. The Karl case was appealed to the Court of Appeals. In an opinion not too helpful in predicting future developments that court held ${ }^{105}$ that the Court of Claims had found as a fact that the accident had occurred as a result of the negligence of state employees, that these findings had not been disturbed, and that therefore the findings must be taken as affirmed. Under this reasoning it sustained an award to claimant. Thus if the court finds that the "defect" is the result of negligence of a state officer or employee it is actionable under the Court of Claims Act provision. Of course it would have been much more satisfactory if the court had wiped out entirely the distinction between a defect in the highway due to negligence and other types of negligence which result in injuries to persons or property on the highways of the state, at least in so far as time limitations on waiver of immunity are concerned. Any argument based on legislative intent or on implied repeals is admittedly difficult to sustain. Yet concededly the state is not an insurer of the safety of its highways, and it is most difficult to imagine any "defect" which is not the result of personal negligence and for which the state has not assumed liability when it consents to the application of respondeat superior against itself.

\section{Procedure in the Court of Claims}

Under the statute regulating the jurisdiction and practice in the Court of Claims which was repealed in 1939 at the time of the enactment of the present Court of Claims Act, ${ }^{106}$ it had become well settled that several of the procedural provisions were actually jurisdictional, in the sense that consent to suit had not been given unless there was absolute compliance on the part of the claimant. ${ }^{107}$ For instance, it was required that claimant file his claim both with the clerk of the court and with the attorney general..$^{108}$ The rules of the court required a claimant to file several additional copies with the clerk, ${ }^{109}$ and the practice was for the clerk to transmit

${ }^{101}$ Karl v. State, 279 N. Y. 555 , I 8 N. E. (2d) 852 (1939).

${ }^{102}$ Logan v. State, 254 App. Div. 410,5 N. Y. S. (2d) 908 (3d Dept., 1938).

${ }^{103}$ Cf. Miller v. State, supra note 97; Hinds v. State, supra note 97.

${ }^{104} 255$ App. Div. 825, 7 N. Y. S. (2d) I31 (4th Dept., 1938). In this case, the particular "defect" was a "fat spot," on the highway, i.e., an excessive amount of bituminous material very smooth and slippery when wet. This would have been considered a "defect" rather than personal negligence under previous holdings. See Killoran v. State, supro note 97.

${ }^{105} 279$ N. Y. $555,559,18$ N. E. (2d) 852,853 (1939).

${ }^{100}$ Supra note 2.

${ }^{107}$ See LAw Revision Commission, supra note 51, 975-991. Buckles v. State, 221 N. Y. 418, 424, 117 N. E. 8II (I9I7): "When, therefore, the legislature in granting permission to prosecute an action against the state required notice of intention to be filed, that condition must be complied with in order to subject the state to an action ... the present judgment cannot be allowed to stand without ignoring the conditions which the legislature has seen fit to impose in permitting actions to be maintained against the state." See also Gates v. State, 128 N. Y. 221,28 N. E. 373 (1891).

${ }^{108}$ Sec former Court of Claims Act (1920, as amended), $\$ 12,15,16$. Sec Court of Claims Act (r939), §Ir.

${ }^{100}$ Rules of the N. Y. Court of Claims, rule II. 
copies to the attorney general. Failure of the claimant himself to file with the attorney general a notice of intention to file a claim, although he had filed it with the clerk and had filed his claim with both officers, was a jurisdictional defect which no one except the legislature itself could waive. ${ }^{110}$ Likewise it was necessary for the claimant to include an allegation as to whether or not the claim was assigned, to enable the court to determine the availability of possible counterclaims, as well as an allegation as to whether the claim had been submitted to any other tribunal for audit or determination, because the jurisdiction of the court was specifically limited and defined in such instances. ${ }^{111}$ The jurisdictional (i.e., consent to suit) provisions were merged with the practice provisions, and it would be safe to say that any practice requirement specifically made applicable to the claimant was jurisdictional in the sense that there was no consent to suit in the event that it was not obeyed.

To a limited extent the present act maintains this rule. It specifically limits its waiver of immunity from liability and action by a proviso that the claimant must comply with the provisions of this article. ${ }^{112}$ The word "article" is however helpful, for it is the second article of the act with reference to jurisdiction of the court which is meant. The practice provisions have been set up as a separate third article of the statute and presumably are not therefore jurisdictional limitations. The statutes of limitations are specifically jurisdictional. ${ }^{113}$ A death claim must be filed within ninety days from the appointment of an executor or administrator of decedent. A claim for injury to person or property must be filed within ninety days from the accrual of the claim. In lieu of filing a claim within ninety days in both of these instances, a notice of intention to sue may be filed within ninety days, and the claim itself filed within two years of the death of the decedent or the accrual of the claim in a personal injury or property damage case. ${ }^{114}$ In the event of failure so to file a claim or notice of intention within ninety days, liberal powers to excuse the error are given to the court in its discretion, upon application, before the expiration of the two-year period as stated above. ${ }^{115}$ In the case of disabilities, the claim may be presented within two years after the removal of the disability. ${ }^{116}$ No judgment may be awarded on a claim which, as between citizens of the stațe, would be barred by lapse of time. ${ }^{117}$ Claims or notices of intention must still be filed with the clerk and with the attorney general, except that the court may excuse the failure to file with the attorney general if the clerk of the court shall have delivered a copy within the time required.118

The rules of pleading are simple: Claimant must state in his claim the time when

210 Buckles v. State, supra note 107.

${ }^{111}$ See former Court of Claims Act (1920, as amended) $\$ 12$. No comparable provision is included in the present statute.

${ }_{123}$ N. Y. Court of Claims Act, $§ 8$.

113 They are included within Article II, entitled "Jurisdiction." See supra note II2.

114 N. Y. Court of Claims Act, $\$ 10(2)(3) . \quad{ }^{115} I d . \$ \$ 10(5)$, II. $\quad{ }^{210} I d . \$ 10(5)$.

${ }^{117}$ N. Y. Const., Art. iii, \$19; N. Y. Court of Claims Act, $\$ 12(2)$. See Oswego \& Syracuse R. R. v. State, 226 N. Y. 35I, I24 N. E. 8 (IgI9). See also discussion in LAW Revision Conm'N supra note 5I, 976-979.

${ }_{118}$ N. Y. Court of Claims Act, $§ 11$. 
and place where the claim arose, the nature thereof, and the items of damage or injuries claimed to have been sustained, as well as the total sum claimed. ${ }^{110}$ The notice of intention, however, need not contain the itemization or the total amount demanded. ${ }^{120}$ The rules of the court require the claimant to state whether or not the claim has been assigned and if so the name and address of all persons interested and the nature and extent of such interest. ${ }^{121}$ The date of filing of a notice of intention must be pleaded, and if the action is brought under a special statute, the statute must be pleaded. ${ }^{122}$ Verification is required. ${ }^{123}$ The court itself publishes suggested forms within an appendix to its rules, although it is stated that these forms as such have not been approved by the court. ${ }^{124}$ The state may counterclaim against claimant on any cause of action in favor of the state against the claimant, or against his assignor existing at the time of the assignment. ${ }^{125}$ Parties claimant may be individuals, corporations or municipalities. ${ }^{126}$ No pleading is required on the part of the state; all allegations in the claim are treated as denied. ${ }^{127}$ If a counterclaim is interposed, however, obviously a pleading is required in the same form as required of claims, and in this event a claimant must file a reply. ${ }^{128}$ Motions in the nature of demurrers may be submitted to the court on eight days' notice, for dismissal of a claim or counterclaim on the ground that a cause of action is not stated, or on the ground of lack of jurisdiction of the claim or subject matter. ${ }^{128}$ The court has liberal powers to permit amendments, ${ }^{130}$ to order claims tried together with or without consolidation, ${ }^{131}$ to open up defaults, ${ }^{132}$ to reopen trials for further evidence ${ }^{133}$ and to grant new trials in accordance with the powers of the supreme court in ordinary civil actions. ${ }^{134}$ It may order the bringing in of additional parties (called, in the statute, interpleader) whenever necessary for the complete determination of the claim or counterclaim, and a procedure for such bringing in of parties is prescribed. ${ }^{135}$ No provision is made, however, for interpleader to determine adverse claims, such as that permitted in equity and under special statutes in the Supreme Court practice. ${ }^{136}$ The state may have an examination of the claimant before trial on a simple five days' notice on any facts involved in any type of claim. ${ }^{137}$ The claimant may get an order from the court for the examination of any state officer or employee or witnesses with regard to certain facts with somewhat the same limitations as the Civil Practice Act makes in ordinary civil actions with regard to examinations before trial of adverse parties or witnesses. ${ }^{138}$ Trial is had without a jury before one judge and judgment is rendered by one judge unless the presiding judge orders a three-

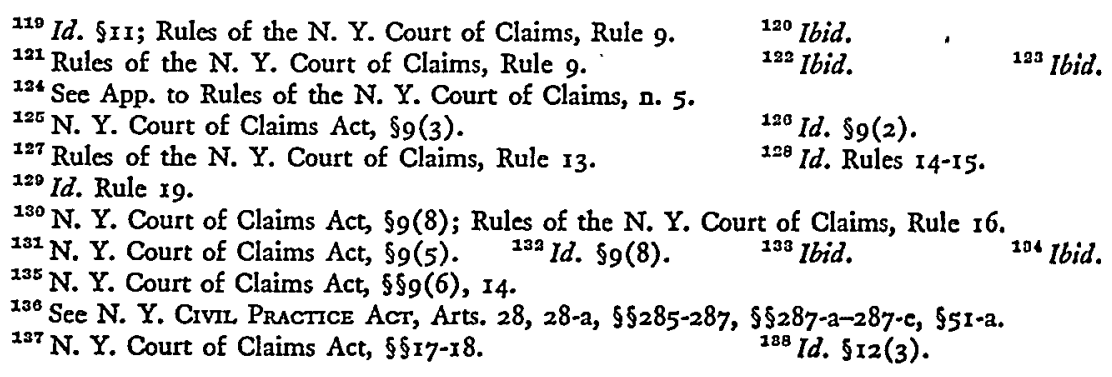


man court, in which event concurrence of two judges is necessary for decision. ${ }^{130}$ Intermediate motions and applications are heard by one judge. ${ }^{140}$ Briefs and requests for findings of fact and conclusions of law may be submitted, and usually are, and exhibits are retained by the parties after trial until demanded by the clerk. ${ }^{141}$ The trial results in a decision by the court, on which a judgment is entered. ${ }^{142}$ After the entry of a judgment in favor of claimant, the Comptroller of the state, upon consent of the Attorney General, may pay such part of the judgment as is not the subject of an appeal by the state, or upon order of the Appellate Division may be compelled to do so. ${ }^{143}$ No judgment may be paid without a certified copy thereof being filed with the comptroller, together with a certificate of no appeal from the Attorney General, and a release and waiver of attorney's lien by the attorney for the claimant. ${ }^{144}$ The legislature annually appropriates a lump sum amount for the payment of Court of Claims judgments. ${ }^{145}$

Appeals from judgments of the Court of Claims are taken to the Appellate Division, Third Department, of the Supreme Court except that claims which arose in the Fourth Department are taken to the Appellate Division for that Department. ${ }^{146}$ Under the provisions which govern the jurisdiction of the Court of Appeals, appeals may be taken ultimately to that court. ${ }^{147}$ No costs or disbursements are allowed in the Court of Claims except that an allowance for searches and abstracts must be allowed in land appropriation cases. ${ }^{148}$

Except in the case of canal claims there are no provisions permitting the state to settle claims made against it. In canal claims the superintendent of public works with the consent of the state may make settlement of claims where the amount thereof does not exceed five hundred dollars. ${ }^{149}$ In other cases a specific provision against implying liability prevents actual settlements. ${ }^{\mathbf{1 5 0}}$ There are, however, two specific practices which are analogous to settlements. Where a compromise is actually agreeable to both parties, the court often hears the proof of claimant, and the state offers no proof, the assistant attorney general in charge informing the court that an award of a specified sum is not objectionable. There is also a specific rule permitting the submission of a case to the court on an agreed statement of facts. ${ }^{151}$ The expense of a trial in the court often makes it difficult in minor cases for a claimant to present his facts, especially in view of the fact that no costs may be allowed. ${ }^{152}$ It would be well if the legislature were to permit the settlement of small cases generally as it has already done in the case of canal claims.

${ }^{130} \mathrm{Ibid}$. $\quad{ }^{140} \mathrm{Ibid}$. Rules of the N. Y. Court of Claims, Rules $26,27$.

${ }^{143}$ N. Y. Court of Claims Act, $\S 20$. Rules of the N. Y. Court of Claims, Rule 28 . In the appendix to its rules, the Court publishes, unofficially, suggested forms of judgments.

${ }_{143}$ N. Y. Court of Claims Act, $\$ 20(5)$.

14' Id. $\$ 20(6)$. The Court itself has published notes on the drafting of judgments and the procedure

to obtain payment. See appendix to rules of the Court of Claims.

${ }^{145}$ See appendix to this article, infra. $\quad{ }^{146} \mathrm{~N}$. Y. Court of Claims Act, $\$ \$ 24-26$.

${ }^{147}$ N. Y. Civil Practice Act, $\$ 589(\mathrm{I})$. For the jurisdiction of the Court of Appeals, see N. Y.

Const., Art. vi, §7; N. Y. CrviL PRACTICE ACr, Art. 38 .

${ }^{148}$ N. Y. Court of Claims Act, $\$ \$ 27,28 .{ }^{140}$ N. Y. Canal Law, $\S 120$.

${ }_{100}^{100}$ N. Y. Court of Claims Act, $\$ 12(x)$.

${ }^{151}$ Rules of the N. Y. Court of Claims, Rule 18.

${ }^{163}$ N. Y. Court of Claims Act, $\$ 27$. 


\section{(a) In general}

\section{Administration of the System}

The principal offices concerned in the administration of tort liability in New York are those of the court itself, of the Attorney General, of the Department of Public Works, and of the Department of Audit and Control.

The organization of the Court of Claims itself has already been discussed. ${ }^{153}$

In the office of the Attorney General, a bureau of claims has been organized consisting of two divisions, litigation and investigation. An assistant attorney general is in charge. He supervises sixteen assistant attorneys general, of whom twelve are situated in Albany, three in New York City and one at Rochester. In the division of investigation and appraisal there is a supervising claims investigator who reports to the assistant attorney general in charge of the bureau. This official is assisted by nine claims invesigators, of whom seven are in Albany, one in New York City, and one in Buffalo. Ten stenographers and clerks are assigned to the bureau, the total budgetary expense being, for I94I, $\$ \mathrm{I} 48,970$ for personal service and $\$ 4 \mathrm{I}, 250$ for maintenance and operation, the latter item including funds for printing, equipment and supplies, travel, communication and fees for experts and other witnesses. ${ }^{154}$

In the Department of Public Works, which has the power to agree on value with the land owner prior to filing a claim in appropriation cases when land is taken for grade crossing eliminations, canal improvements or flood prevention, and which also has the duty of preparing the factual defense in contract and tort cases with the staff of the Attorney General, there is also a division which devotes itself to Court of Claims practice. In land appropriation cases there is an associate land and claim adjuster who is assisted by four men who devote their entire time to investigation and appraisal in this type of case. Then there is a principal claims engineer who is assisted by three engineers permanently assigned to his office, who prepares the defense from an engineering point of view in contract cases, and who provide the office of the attorney general with the initial statement of facts in tort cases. Both in contract and in tort cases this office furnishes the Attorney General with such factual and expert witnesses as may be required. Obviously in many tort cases these witnesses and experts must come from other state departments who are involved in a particular claim in litigation. ${ }^{155}$

The Department of Audit and Control is concerned with the payment of judg. ments of the court. Judgments on account of damages caused by the canals are handled by one person employed in the canal bureau. Judgments for appropriations of land are handled by the land division of the audit bureau. Judgments for damages from grade crossing eliminations are handled by the highway division of the audit bureau. Both of these divisions have of course many other functions and duties. All other judgments of the court, for contract or tort, are handled by one person in

${ }^{163}$ Supra notes 25-42.

${ }^{154}$ Letter, Hon. John J. Bennett, Attorney-General of New York, to the writer, Feb. 24, 1942.

${ }^{155}$ Letter, Hon. Arthur W. Brandt, Superintendent of Public Works of New York, to the writer, Feb. 21, 1942. 
the executive division of the office, assigned to this work in conjunction with other duties. 156

\section{(b) Investigation and Compromise}

When a claim or notice of intention to file a claim is filed, it is first referred to the Assistant Attorney General in charge of the Bureau of Claims. He refers it to the Supervising Claims Investigator, who causes an investigation to be made, consults with the department of government concerned, interviews witnesses, obtains experts, photographs, maps, etc., and prepares a report. Due to the great number of claims which involves matters under the control of the Department of Public Works (e.g., highways, canals, public buildings, etc.) the services of the principal claims engineer in that office are much in demand, and the specialization which obtains in that department is essential. Upon rendition of a report, the assistant attorney general in charge assigns the claim when filed to an assistant, who prepares the case for trial.

Canal cases up to $\$ 500$ may be settled by the Department of Public Works without filing of a claim. ${ }^{157}$ There is no comparable provision in other types of cases. As liability against the state may not be implied, settlements in other types of cases are possible only after filing of a claim, by the state's presenting no evidence when the claim is reached for trial, and by a statement at that time that no objection is made to an award in a stated amount. ${ }^{158}$

\section{(c) Litigation}

Litigation is conducted before a court composed of either one or three judges. ${ }^{159}$ A deputy clerk of the court acts as court stenographer. The assistant attorney general who has been assigned to the case by the assistant in charge of the bureau of claims tries the case. $\mathrm{He}$ is assisted by the investigator from his own department and usually by the principal claims engineer from the Department of Public Works. Witnesses from other state departments or from outside the state government have been obtained and are present. Sometimes assistance during the trial is rendered by other state officers and employees.

\section{(d) Payment of Awards}

There is no way possible to estimate the amount of awards of the Court of Claims during a prospective fiscal year. Hence the budget bill of the state carries a lump sum appropriation annually for judgments of the Court of Claims. ${ }^{160}$ Invariably the amount of the judgments have exceeded the appropriation. When the amount appropriated is exhausted, the Comptroller purchases the judgment, thus paying the claimant, as an investment for the sinking funds of the state pursuant to law, and when a new appropriation is available, these sinking funds are reimbursed with interest as allowed by law when computing interest for the payment of judgments. ${ }^{161}$

\footnotetext{
${ }^{100}$ Letter, Hon. Joseph V. O'Leary, Comptroller of the State of New York, to the writer, March 2, 1942.

${ }_{157}$ Sipra note 149.

${ }^{150}$ Supra note 138 .

${ }^{158}$ Supra note 150.

${ }^{180}$ See appendix to this article, infra p. $28 \mathrm{I}$.

${ }^{101}$ See N. Y. Court of 'Claims Act, $\$ 20(7)(8)$; N. Y. State Finance Law, \$98(4). See (19r6) Ops،
} 
This procedure meets effectively the problem of enforceability of a judgment against the state, since payment by this method may be compelled by the claimant, whereas no remedy could be made available to a judgment creditor to compel an appropriation. $^{162}$

\section{Conciustons}

Certain conclusions may be drawn from the history of state liability in New York. ${ }^{163}$ Some are obviously mere personal opinion, but some have a very definite foundation in the development of the law.

I. The "honesty of sovereignties" will not result in the bankruptcy of sovereignties. The amount of awards of the Court of Claims in New York does not exceed even one percent of the state budget. These total awards are inclusive of obligations which the state must constitutionally pay to support its exercise of the power of eminent domain, of obligations in contract which every state must meet in order to maintain its credit, as well as of awards in tort. It may be assumed that the awards in tort claims are not a large percentage of the total awards.

2. The system of making awards by specific legislative enactment, as is done in Congress, or of conferring jurisdiction in specific cases on a court or board of claims as was done in New York prior to 1929 , is undesirable and ineffective.

3. Jurisdiction over suits against the state should be conferred on a special state tribunal,

(a) because of the specialized knowledge it will acquire in contract and land appropriation cases

(b) because, it does not subject the state as a defendant to the prejudices af particular localities

(c) because it insures a uniform point of view on unliquidated damage cases arising throughout the state.

4. This tribunal should be a court, rather than an administrative agency, with judicial powers, a court of 'record, of equal dignity with the major court of original jurisdiction in private law cases in the state.

5. The court so created should have a constitutional, rather than a legislative, status. ${ }^{164}$

AtT'y Gen. 358; (1925) Ops. ATr'y Gen. 13I; (1926) Ops. AtT'y Gen. 73. See also note on the binding character of a judgment against the state, (1932) I7 ConN. L. Q. 254.

${ }^{102}$ See Maguire, State Liability for Tort (1916) 30 Harv. L. Rev. 20; Zane, A Legal Heresy (1918) 13 ILI. L. Rev. 431; Martindale, The State and its Creditors (1882) 7 So. L. Rev. (N. S.) 544, 548; Freund, Private Claims Against the State (1893) 8 PoL. Scr. Q. 625, 639. See also Mr. Justice Holmes in Kawanakoa v. Polyblank, 205 U. S. 349, 353 (1907).

${ }^{103}$ No attempt has been made here to make suggestions with regard to the improvements in the practice of the Court of Claims, in so far as the problem seems to be local. For instance, it might be suggested that the Judicial Council require a breakdown in the statistics which arc filed by the clerk in order to make possible further study, similar to that reported in David and Feldmeier, The ADMinistration of Tort Linbility in Los ANGeles (Committec on Public Administration, Social Science Research Council, 1939). Likewise, it might be suggested that some procedure be adopted for the determination of adverse claims, supra notes $35-36$. In some instances, too, a removal proceeding from the Court of Claims to the Supreme Court might be considered where suit is brought for personal negligence against the tort-feasor and also suit against the state, respondeat superior.

104 For recent developments in New York, see supra note 18. 
6. The tenure of office and salary of its judges should be equal to those of the major court of original jurisdiction in private law cases in the state.

7. In assuming liability, care must be taken to enact a statute which will both waive immunity from suit, and in addition assume a substantive liability identical with that of individuals and corporations.

8. A means should be found to enable the state to settle, below a specified figure, claims made against it, upon which liability may be conceded.

9. Care should be taken to avoid making rules of procedure in the tribunal limitations upon the consent to suit, thus resulting in undue restrictions upon jurisdiction.

Io. Obviously statutes of limitations and notice provisions will be strict. The tribunal should be given discretionary powers within limits to excuse prompt filing of claims if floods of special claims statutes are to be avoided.

II. When the system of state liability is set up and is found satisfactory, constitutional limitations upon the power of the legislature to pass claim bills should be enacted, and a constitutional assumption of liability should be made.

\section{APPENDIX}

TABLE I

The Volume of Business in the New York Court of Claims

\begin{tabular}{|c|c|c|c|c|c|c|c|c|c|c|c|c|c|}
\hline Period & 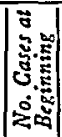 & 苞 & छัँ & 焉 & 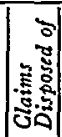 & 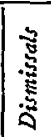 & 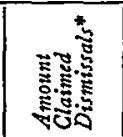 & 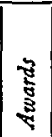 & 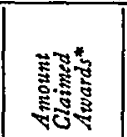 & 卷 & 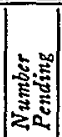 & 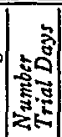 & 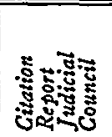 \\
\hline $\begin{array}{c}1 / 1 / 1935 \text { to } \\
6 / 30 / 1935 .\end{array}$ & 1141 & & 121 & & 412 & 306 & & 106 & & & 850 & $\ldots$ & 36 , p. 62 \\
\hline $\begin{array}{l}7 / 1 / 1935 \text { to } \\
6 / 30 / 1936 .\end{array}$ & 850 & $\$ 27,977,982$ & 457 & $88,425,792$ & 441 & 242 & $86,762,086$ & 199 & $\$ 4,330,684$ & $\$ 1,048,472$ & 866 & 341 & 37 , p. 79 \\
\hline $\begin{array}{l}7 / 1 / 1936 \text { to } \\
6 / 30 / 1937 .\end{array}$ & 866 & $25,311,005$ & 410 & $5,211,674$ & 408 & 263 & $4,010,407$ & 145 & $2,541,603$ & $1,055,512$ & 868 & 306 & '38, p. 95 \\
\hline $\begin{array}{l}7 / 1 / 1937 \text { to } \\
6 / 30 / 1938 .\end{array}$ & 868 & $23,970,667$ & 372 & $10,175,671$ & 310 & 193 & $2,607,039$ & 117 & $8,454,943$ & $2,149,816$ & 930 & 402 & '39, p. 95 \\
\hline $\begin{array}{c}7 / 1 / 1938 \text { to } \\
6 / 30 / 1939 . .\end{array}$ & +936 & $23,153,151$ & 229 & $15,147,417$ & 314 & 180 & $9,396,841$ & 134 & $2,798,808$ & 791,438 & 851 & 391 & '40, p. 97 \\
\hline $\begin{array}{l}7 / 1 / 1939 \text { to } \\
6 / 30 / 1940 . .\end{array}$ & 851 & $26,104,918$ & 353 & $4,186,564$ & 334 & 181 & $7,778,739$ & 153 & $2,936,761$ & 745,910 & 870 & 400 & ' 41, p. 104 \\
\hline $\begin{array}{l}7 / 1 / 1940 \text { to } \\
6 / 30 / 1941 . .\end{array}$ & 870 & $19,575,981$ & 359 & $3,324,583$ & 363 & 217 & $2,467,175$ & 146 & $2,222,930$ & 498,023 & 866 & 431 & '42 p. 110 \\
\hline
\end{tabular}

*Cents omitted. 16 claims restored.

Table II

Appropriations aird Awards-Court of Ciaims Judgments

\begin{tabular}{|c|c|c|c|}
\hline Fiscal Year & Amount Appropriated & Citation & Atoards \\
\hline $7 / 1 / 1935$ to $6 / 30 / 1936 \ldots .$. & $\$ 500,000.00$ & Laws 1935, c. 51, p. 454 & $\$ 1,048,472.52$ \\
\hline $7 / 1 / 1936$ to $6 / 30 / 1937 \ldots .$. & $500,000.00$ & Laws 1936 , c. 168, p. 475 & $1,055,512.31$ \\
\hline $7 / 1 / 1937$ to $6 / 30 / 1938 . . . .$. & $750,000,00$ & Laws 1937 , c. 126 , p. 550 & $2,149,816.65$ \\
\hline $7 / 1 / 1938$ to $6 / 30 / 1939 \ldots \ldots$ & $750,000.00$ & Laws 1938 , c. 19, p. 32 & $791,438.82$ \\
\hline $7 / 1 / 1939$ to $6 / 30 / 1940 \ldots .$. & $750,000.00$ & Laws 1939 , c. 461 , p. 1154 & $745,910.84$ \\
\hline $7 / 1 / 1940$ to $6 / 30 / 1941 \ldots \ldots$ & $\begin{array}{l}\text { (a) } 750,000.00 \\
\text { (b) } 301,623.01\end{array}$ & $\begin{array}{l}\text { (a) Laws } 1940 \text {, c. } 128, \text { p. } 637 \\
\text { (b) Laws } 1940 \text {, c. } 877, \text { p. } 2184\end{array}$ & $498,023.76$ \\
\hline $7 / 1 / 1941$ to $6 / 30 / 1942 \ldots \ldots$ & $1,050,000.00$ & Laws 1941, c. 101, p. 622 & ......... \\
\hline
\end{tabular}

